\title{
Uma outra modernização. Transportes em uma província não exportadora - Minas Gerais, $1850-1870^{1}$ \\ Marcelo Magalhães Godoy ${ }^{2}$ \\ Lidiany Silva Barbosa ${ }^{3}$
}

\section{Resumo}

Entre 1750 e 1880, Minas Gerais desenvolveu economia com o predomínio de direção não exportadora da produção e relativa independência em relação a mercados externos de outros espaços regionais do Brasil e do exterior do país. Essa singular evolução histórica ensejou específica compreensão e tratamento do problema dos transportes pelos contemporâneos. No século XIX, sobretudo em seu terceiro quartel, estavam postas as condições para que o processo de modernização dos transportes em Minas, sobretudo na forma da aceleração da constituição de sistema integrado, se realizasse fora das determinações da hegemonia de modelo econômico primário-exportador. Neste escrito, são avançadas reflexões em torno da história dos transportes na província de Minas Gerais e apresentadas e analisadas evidências documentais que demonstram o quanto pode ser equivocada apreensão da modernização dos transportes no Brasil que considere modelo único ou que tenda a generalizar para o conjunto do país a experiência histórica da modernização com base no ferroviarismo.

Palavras-chave: Transportes; Formação do mercado interno; Processo de modernização; Província de Minas Gerais.

\section{Abstract \\ Another modernization: transportation in a non-exporting province - Minas Gerais, 1850 - 1870}

Between 1750 and 1880, Minas Gerais developed an economy predominantly non-exporting as well as relatively independent of external markets of other Brazilian regions and of foreign markets. Due

(1) Trabalho recebido em março de 2007 e aprovado em outubro de 2007. Desenvolvido no Núcleo de Pesquisa em História Econômica e Demográfica do Centro de Desenvolvimento e Planejamento Regional da Universidade Federal de Minas Gerais (Cedeplar/UFMG), esta linha de pesquisa conta com o apoio da Fundação de Amparo à Pesquisa de Minas Gerais, no âmbito do projeto Sistema de transportes de Minas Gerais - 18501930, e da Pró-Reitoria de Pesquisa da UFMG, através do Programa de Auxílio para Pesquisa dos RecémDoutores. O recolhimento de dados no Arquivo Público Mineiro foi realizado pelas bolsistas de Iniciação Científica Elaine Costa Aguiar e Wanessa Ferreira de Souza, a quem os autores agradecem. Também são gratos pelo trabalho cartográfico elaborado por Rafael Rangel Giovanini, com base em informações coletadas no Atlas do Brazil (Homem de Mello; Homem de Mello, 1909).

(2) Doutor em História Econômica pela Universidade de São Paulo (USP). Professor do Departamento de Ciências Econômicas e do Cedeplar da Faculdade de Ciências Econômicas da UFMG. Pesquisador associado ao Núcleo de Pesquisa em Histórica Econômica e Demográfica do Cedeplar/UFMG, Belo Horizonte, MG, Brasil. E-mail: mmgodoy@ cedeplar.ufmg.br.

(3) Doutoranda em História Social pela Universidade Federal do Rio de Janeiro (UFRJ). Pesquisadora associada ao Núcleo de Pesquisa em História Econômica e Demográfica do Cedeplar/UFMG, Belo Horizonte, MG, Brasil. E-mail: lidiany@ cedeplar.ufmg.br. 
Marcelo Magalhães Godoy / Lidiany Silva Barbosa

to such unique historical evolution, contemporaries had to develop specific understanding and ways of dealing with transportation problems. In nineteenth century, mainly in its third quarter, it were established the conditions for the modernization process of transportation in Minas. Those conditions allowed such modernization to take place apart from the determinations resulting from the hegemony of a primarily exportation economic model, specially based on hastening the construction of an integrated system. This text enlarges considerations about the history of transportation in the province of Minas Gerais. It presents and analyses documental evidences which demonstrate it can be mistaken the understanding of modernization of Brazilian transportation considering a single model as well as the tendency to generalize to the whole country the historical experience of modernization based upon a railroad system.

Key words: Transportation; Constitution of domestic market; Modernization process; Province of Minas Gerais.

JEL N46, N76, N96.

O caminhão chegou tarde demais para privar Minas de uma longa e custosa paixão pelo cavalo de aço (Wirth, 1982, p. 105).

\section{Introdução}

Entre 1750 e 1880, Minas Gerais desenvolveu economia com o predomínio de direção não exportadora da produção e relativa independência em relação a mercados externos de outros espaços regionais do Brasil e do exterior do país. Essa singular evolução histórica ensejou específica compreensão e tratamento do problema dos transportes pelos contemporâneos. No século XIX, sobretudo em seu terceiro quartel, estavam postas as condições para que o processo de modernização dos transportes em Minas, sobretudo na forma da aceleração da constituição de sistema integrado, se realizasse fora das determinações da hegemonia de modelo econômico primário-exportador. Neste escrito, são avançadas reflexões em torno da história dos transportes na província de Minas Gerais e apresentadas e analisadas evidências documentais que demonstram o quanto pode ser equivocada apreensão da modernização dos transportes no Brasil que considere modelo único ou que tenda a generalizar para o conjunto do país a experiência histórica da modernização com base no ferroviarismo.

A modernização dos transportes constituiu fator fundamental do processo de formação do mercado interno capitalista brasileiro. No transcurso da segunda metade do século XIX e primeiras décadas da centúria seguinte, em parcela expressiva do território nacional, surge e desenvolve-se sistema de transportes moderno, que amplia consideravelmente as articulações inter-regionais, notadamente no Sudeste, e integra o mercado interno em bases capitalistas. 
Conquanto sejam discerníveis processos integrativos anteriores a 1850, sobretudo associados à evolução histórica de Minas Gerais, foi somente nas duas últimas quadras do Oitocentos que a combinação de várias transformações na economia e sociedade brasileira impulsionou, irreversivelmente, a formação de mercado interno integrado (Paula, 2002, p. 32). Nesse quadro, era imperativo superar os limites da infra-estrutura tradicional de transportes e criar condições para: a quebra do isolamento geográfico dos mercados regionais, a diminuição dos custos dos transportes e comunicações, a dinamização da circulação de pessoas e mercadorias, a redução dos diferenciais de preços regionais e a universalização da circulação de informações.

Articuladas à modernização dos transportes, diversas transformações econômicas, sociais, políticas, jurídicas e institucionais combinaram-se no processo de modernização do Brasil, forjando mercado interno capitalista. O Estado desempenhou papel central na criação das condições para a efetivação dessas transformações, como no processo de transição do trabalho escravo para o livre e a constituição de mercado de trabalho assalariado, no estabelecimento da propriedade territorial juridicamente plena e formação de mercado de terras capitalista, ou ainda na modernização das relações comerciais e financeiras (Paula, 2002, p. 17). Dessa forma, considera-se imprescindível entender a evolução dos transportes, referenciada no contexto histórico da transição para economia capitalista de base urbano-industrial.

O enquadramento da modernização dos transportes na conjuntura de longa duração da transição para o capitalismo industrial não pode prescindir da reconstituição das condições históricas específicas, notadamente em suas particularidades regionais, da passagem de padrão tradicional de transportes para sistema integrado. $\mathrm{O}$ risco de anacronismo histórico tanto maior será quanto mais se considere um único modelo de modernização. $\mathrm{O}$ advento da "era ferroviária" no Brasil foi marcado pela assimetria, ou por grandes contrastes regionais entre o ritmo e alcance da implantação de estradas de ferro (Natal, 1991, p. 48-55). Em alguns espaços regionais, as ferrovias jamais suplantaram os transportes tradicionais, prevalecendo modelo de desenvolvimento assente em estradas de rodagem.

A percepção da vigência de modelo único de modernização dos transportes é uma das prováveis consequiências da tendência da historiografia brasileira a desconsiderar a experiência histórica dos espaços econômicos não exportadores e os circuitos mercantis internos. ${ }^{4}$ A esse tipo de enquadramento p. 163-166).

(4) A referida tendência foi objeto de reflexão de José Roberto do Amaral Lapa em texto recente (2002, 
predominante corresponde a suposição de que todas as outras experiências históricas não se desdobraram em modernização, ou, ao menos, a tiveram retardada. Mais ainda, dada a estreita relação entre ferrovias e atividades agroexportadoras (Natal, 1991, p. 62), parece subentendido que somente determinado tipo de inserção internacional poderia sustentar transformações significativas, ou modernizantes, nos transportes. Prevalece, portanto, a tendência a desconsiderar trajetórias históricas em que se confrontaram distintos padrões de desenvolvimento, experiências concretas que ensejaram as condições necessárias para a construção de alternativa ao modelo agrário-exportador. Desdobramento dessa predominante orientação teórica e da exigüidade de estudos sobre a navegação fluvial e o desenvolvimento rodoviário anteriores ao século XX é a aparente escassez de fontes para o estudo dos transportes não ferroviários se comparada com as disponíveis para os ferroviários (Queiroz, 2000, p. 133). ${ }^{5}$

A eleição do estudo da modernização dos transportes de Minas Gerais, em sua fase inicial ou na terceira quadra do século XIX, justifica-se por quatro razões fundamentais: i. a evolução histórica de Minas até meados do Oitocentos não apenas é singular, como talvez seja a única experiência da passagem de dinâmica economia escravista orientada para o exterior para dinâmica economia escravista orientada para o mercado interno; ii. desde meados do século XVIII, intensifica-se processo de substituição de importações que sustentará grande desenvolvimento de atividades agropecuárias e de transformação e culminará em reduzida dependência externa da economia de Minas Gerais; iii. ao final da primeira metade do século XIX, estavam reunidas em Minas Gerais as condições para a conversão de "desenvolvimento independente" em processo de fortalecimento do mercado interno e política industrialista impulsionada pela conversão da proteção geográfica e dos custos elevados dos transportes em protecionismo tarifário; iv. durante o período de crescimento econômico de Minas Gerais, entre 1750 e 1850, os transportes tradicionais ${ }^{6}$ atenderam às necessidades internas e externas de comunicação e em meados do século XIX estavam postas as condições para

(5) Com base em levantamento realizado pela Anpuh (Capelato, 1995), Paulo Roberto Cimo Queiroz avalia as teses e dissertações defendidas no Brasil, entre os anos 1985 e 1994. O autor constata que, dos 29 estudos diretamente ligados aos transportes e comunicações, 11 são sobre ferrovias e os demais 18 tratam dos seguintes temas: três sobre tropas coloniais, três sobre rádio, três sobre navegação fluvial, dois sobre navegação de cabotagem, dois sobre construção naval, dois sobre portos, dois sobre aviação, um sobre telefonia e um sobre rodovia. Temos, portanto, o predomínio dos estudos sobre ferrovias, em um cenário de quase completa ausência de estudos referentes aos transportes rodoviários (Queiroz, 2000, p. 133-132). Queiroz salienta que esse quadro está em descompasso com a importância assumida pelas rodovias no século XX.

(6) Consideram-se transportes tradicionais as formas classificadas por José Alípio Goulart, em Meios e Instrumentos de Transportes no Interior do Brasil, mais especificamente aquelas descritas na parte dedicada aos transportes terrestres (Goulart, 1959, p. 119-253). Este trabalho exaustivo procede a levantamento minucioso dos meios e instrumentos de transportes tradicionais, uns já desaparecidos e outros por desaparecer. 
padrão de modernização compatível com o desenvolvimento do mercado interno de Minas.

Além da introdução, o texto foi dividido em quatro partes. Na primeira, são apresentados os "inquéritos provinciais", fontes primárias centrais deste estudo. Discute-se o contexto político-administrativo em que esses documentos foram produzidos e a que propósitos atendiam. Examina-se a dinâmica de elaboração das respostas às solicitações que instruíam os inquéritos, sobretudo as características das requisições, os agentes locais responsáveis pela execução e a cobertura da documentação remanescente. Por fim, avalia-se a representatividade da presença do tema dos transportes no conjunto da documentação. A segunda parte destina-se à síntese dos planos de viação da província de Minas Gerais e à proposição de interpretação do sentido do sistema de transportes que se pretendia construir. Ressalta-se que os planos de viação mineiros refletiam a existência de conflito entre dois modelos de desenvolvimento econômico, qual seja, o conflito entre os imperativos de economia de base primário-exportadora, que convergia para inserção periférica e dependente, e a trajetória histórica de Minas, inclinada para inserção alternativa e independente. Na terceira parte, procede-se à avaliação panorâmica dos transportes de Minas Gerais na passagem do século XIX para a centúria seguinte. Conjunto de representações cartográficas, elaboradas a partir do mapa de Minas Gerais do Atlas do Brazil, de autoria do Barão Homem de Mello e Francisco Homem de Mello, fornece subsídios para compreender alguns aspectos do desenvolvimento dos transportes na última quadra do Oitocentos. Salienta-se da configuração espacial do sistema de transportes em gestação a inclinação para modelo ferroviário, conquanto as estradas de rodagem permaneçam importantes e se apresentem ainda como melhor tradução da evolução histórica de Minas nos séculos XVIII e XIX. Na última parte, realiza-se estudo das informações sobre transportes constantes nos inquéritos provinciais das décadas de 1850 e 1860 . O problema dos transportes é examinado na perspectiva dos municípios, nos imperativos das economias locais e regionais. A tentativa de compreender o sentido das complexas solicitações das municipalidades e freguesias ocupa o primeiro plano da análise da documentação. Vislumbram-se as múltiplas determinações que informavam as autoridades municipais na abordagem do problema dos transportes, a tentativa de traduzir em ofícios enviados ao governo provincial as necessidades de economias locais e regionais que não comportavam qualquer enquadramento a caracterizar-lhes como primário-exportadoras ou inclinadas para esse sentido de desenvolvimento econômico. 
Marcelo Magalhães Godoy / Lidiany Silva Barbosa

\section{Os inquéritos provinciais}

A larga dimensão territorial, forte desconcentração populacional e marcante diversidade regional que caracterizavam o espaço mineiro impunham a necessidade de comunicação regular entre as regiões e o governo provincial. As circunscrições administrativas, mormente as municipalidades e freguesias, atendiam a recorrentes solicitações sobre temas variados: população, economia, infra-estrutura urbana, transportes e comunicações, saneamento e saúde, educação e administração. Embora o debate e disputa entre propostas e intenções centralizadoras versus descentralizadoras tenham marcado a evolução políticoadministrativa do Império, o predomínio das primeiras colaborou para a instabilidade e falta de autonomia das administrações provinciais (Ferreira, 1999). Em Minas Gerais, a hegemonia centralizadora traduziu-se em dilatado número e efêmera duração média dos períodos dos governos provinciais mineiros, combinados com a nada incomum nomeação de presidentes que desconheciam o fundamental da realidade de Minas Gerais (Iglésias, 1958, p. 37-58). Assim, a descontinuidade e ineficiência administrativas converteram-se em fatores poderosos para impedir que o fluxo de informações entre a Presidência da Província e o grande número de circunscrições administrativas, sejam políticas ou religiosas, estivesse pautado por critério ou racionalidade única. As autoridades locais estavam submetidas a requisições do governo provincial que, em larga medida, caracterizavam-se pela repetição e ausência de clareza. Somam-se, a esse quadro, as relativamente constantes solicitações de informação por parte do governo imperial, reveladoras de desarticulação entre interesses regionais e nacionais ou, em outros termos, da sobreposição de fluxos de informação de origens distintas. Em síntese, pode-se afirmar que os inquéritos provinciais das décadas de 1850 e 1860, fontes documentais precípuas deste estudo, estão inscritos em tradição de circulação de informações públicas em Minas Gerais.

A década de 1850, correspondente a um ponto de inflexão na história econômica do Brasil, constituiu o início de processo de modernização que representou, ainda que gradualmente, a superação de herança colonial. Uma série de reformas de caráter liberal, quase sempre consubstanciadas em disposições jurídicas, intentou estabelecer as bases de nova estrutura econômica. É dessa forma que se compreendem a partida nos processos de mudança do regime legal de apropriação territorial e a constituição de mercado de terra, a transição do trabalho escravo para o livre e a constituição de mercado de trabalho, a criação de marcos regulatórios para as atividades mercantis e a superação de regime comercial caracterizado por permanências coloniais, o estabelecimento das condições para a modernização das relações financeiras e a constituição de mercado de capitais (Paula, 2002, p. 32; Fragoso, 2000, p. 147). Contextualizados 
no quadro dessas transformações, os inquéritos provinciais das décadas de 1850 e 1860 atenderam, a um só tempo, às exigências da referida tradição de circulação de informações públicas em Minas Gerais e aos requisitos específicos das reformas em curso.

As solicitações elaboradas pelo governo de Minas Gerais e enviadas para as autoridades locais da província distinguiam-se pelo predomínio de requisições genéricas, portanto indutoras de respostas impressionistas. Esse padrão de correspondência permitiu amplo espaço para que, no atendimento dos requisitos, fossem incorporadas informações que ultrapassavam os termos definidos na solicitação. Assim, não era incomum que nas respostas aos inquéritos figurassem matérias completamente ausentes das requisições, embora entendidas pelas autoridades locais como indissociáveis dos temas solicitados.

Quase exclusivamente originárias da Presidência da Província, as solicitações atendiam às necessidades de múltiplas instâncias administrativas do governo provincial e deveriam instruir distintos procedimentos públicos: dotação de recursos, realização de obras, lotação de funcionários, resolução de conflitos de jurisdição, instrução de políticas de desenvolvimento, elaboração de estatísticas básicas, exação fiscal, dentre outros.

A dilatada extensão territorial de Minas Gerais implicava grandes variações nas distâncias entre a sede do governo e as sedes das circunscrições administrativas da província. Às distâncias muito variáveis somavam-se as condições também diferenciadas do sistema público de circulação de informação (Rodarte, 1999), fatores relevantes na determinação da eficiência administrativa no atendimento das solicitações do governo provincial.

Contudo, o exame das respostas às solicitações do governo provincial evidencia que os agentes públicos destinatários eram os grandes responsáveis pela heterogeneidade dos conjuntos de documentos que compõem os inquéritos provinciais. Juízes de paz, subdelegados de polícia e párocos traduziam as solicitações de forma pessoal e apresentavam compreensão diversa dos dados requeridos. Os documentos enviados ao governo provincial revelam que a apuração das informações requisitadas e a elaboração dos textos com as respostas foram presididas por diferenciados graus de objetividade, embora predominasse abordagem impressionista, e por diversa dedicação, conquanto fosse majoritário tratamento diligente. Documentação manuscrita, as respostas aos inquéritos provinciais conformam conjunto com múltiplos padrões caligráficos. Ainda que debaixo dos cânones da correspondência pública do século XIX, os documentos enviados ao governo provincial apresentam diagramação por demais variável. 
A cobertura dos inquéritos provinciais das décadas de 1850 e 1860, ou dos documentos remanescentes com as respostas às solicitações do governo provincial, resultou de duas determinantes fundamentais: i. a eficiência do serviço público de correios a assegurar que os inquéritos alcançassem todas as circunscrições administrativas, o zeloso atendimento das requisições dos inquéritos provinciais e a mesma diligência da circulação postal a garantir a entrega no governo provincial das respostas elaboradas pelas autoridades locais (Rodarte, 1999); ii. a eficiência das instâncias ou repartições públicas responsáveis pela guarda e conservação da documentação, de meados do Oitocentos até o início do século XXI. Em outros termos, salvo para alguns inquéritos cujos resultados foram resumidos em relatórios de presidentes da província, é impossível determinar com objetividade qual a extensão do atendimento às solicitações do governo provincial a partir apenas dos documentos remanescentes sob a guarda do Arquivo Público Mineiro.

Para a avaliação da representatividade dos documentos com informações sobre transportes, coligidos a partir do universo de respostas remanescentes dos inquéritos provinciais das décadas de 1850 e 1860, foi utilizada a divisão administrativa válida para o Censo do Império, realizado em Minas Gerais no ano de 1873. Dos 72 municípios existentes no início da década de 1870, as respostas com dados sobre o tema dos transportes cobrem, no conjunto ou parcialmente, 56 municipalidades, ou 78\%. Foram selecionados por volta de 220 documentos referentes a municípios, distritos e paróquias de quase todas as regiões da província. Essa distribuição espacial é índice da universalidade do problema dos transportes, sobretudo se considerado que em apenas um dos inquéritos do período constava quesito específico sobre o tema. Não apenas indicia o lugar destacado dos transportes, assim como, pelas relações estabelecidas com os múltiplos temas das solicitações, revela as articulações com questões de natureza econômica, social, política e administrativa.

No quadro a seguir, são sumariados os temas das solicitações que instruíram a realização dos inquéritos provinciais das décadas de 1850 e 1860 . Essa sinopse objetiva fornecer quadro geral das datas e da natureza dos assuntos perscrutados pelo governo provincial. Na recomposição dos conteúdos dos inquéritos, foram conformados dois padrões: conteúdo integral ou parcial, reproduzidos de alguma resposta, e conteúdo inferido através de respostas constantes que indicavam o perfil do inquérito. Ressalta a convivência de temas próprios à rotina administrativa, com temas que atenderam às exigências das anteriormente mencionadas reformas liberais em curso. Também segue representação cartográfica com a proposta de regionalização para província de Minas Gerais adotada (Godoy, 1996). 
Uma outra modernização. Transportes em uma província não exportadora - Minas Gerais, 1850-1870

Quadro sinóptico dos temas das solicitações dos inquéritos provinciais das décadas de 1850 e 1860

\begin{tabular}{|c|c|c|c|}
\hline Data & Temas & Data & Temas \\
\hline $18 / 12 / 1852$ & $\begin{array}{l}\text { Características gerais da } \\
\text { localidade }\end{array}$ & $22 / 10 / 1857$ & Problemas de abastecimento \\
\hline $04 / 11 / 1853$ & $\begin{array}{l}\text { Implantação de escola normal de } \\
\text { agricultura }\end{array}$ & $07 / 12 / 1857$ & $\begin{array}{l}\text { Eleição para a Assembléia } \\
\text { Provincial }\end{array}$ \\
\hline 25/03/1853 & $\begin{array}{l}\text { Criação de carneiros para } \\
\text { produção de lã }\end{array}$ & $13 / 10 / 1858$ & $\begin{array}{l}\text { Condições sanitárias; informações } \\
\text { sobre a agricultura, indústria, } \\
\text { mineração e comércio }\end{array}$ \\
\hline $28 / 12 / 1853$ & $\begin{array}{l}\text { Mineração, agricultura e indústria } \\
\text { fabril }\end{array}$ & $08 / 09 / 1861$ & Mapa de população \\
\hline $31 / 01 / 1854$ & Colonização & $11 / 09 / 1861$ & Terras devolutas, aviso ministerial \\
\hline 03/04/1854 & $\begin{array}{l}\text { Criação de carneiros para a } \\
\text { produção de lã }\end{array}$ & $18 / 09 / 1861$ & $\begin{array}{l}\text { Inquérito que trata de sesmarias e } \\
\text { características da localidade }\end{array}$ \\
\hline $09 / 11 / 1854$ & Pontes & $04 / 10 / 1861$ & Características gerais da localidade \\
\hline $10 / 11 / 1854$ & Agricultura, comércio, fábricas & $23 / 10 / 1861$ & $\begin{array}{l}\text { Informações sobre agricultura, } \\
\text { indústria e comércio }\end{array}$ \\
\hline $11 / 11 / 1854$ & $\begin{array}{l}\text { Mineração, agricultura, fábricas e } \\
\text { comércio }\end{array}$ & $10 / 11 / 1862$ & $\begin{array}{l}\text { Prestação trimestral de contas das } \\
\text { câmaras; Ministério da Agricultura } \\
\text { sobre produtos agrícolas }\end{array}$ \\
\hline $16 / 03 / 1854$ & Registro de terras & $10 / 11 / 1862$ & Mineração \\
\hline $21 / 09 / 1854$ & Terras obtidas pela posse & $18 / 12 / 1862$ & Descrição da localidade \\
\hline $02 / 05 / 1854$ & Terras obtidas pela posse & $27 / 12 / 1862$ & Receita municipal \\
\hline $31 / 03 / 1855$ & $\begin{array}{l}\text { Colonização, originário do } \\
\text { Governo Geral }\end{array}$ & $10 / 11 / 1862$ & $\begin{array}{l}\text { Descrição das atividades } \\
\text { econômicas principais, inquérito } \\
\text { originário do Governo Geral }\end{array}$ \\
\hline $12 / 04 / 1855$ & $\begin{array}{l}\text { Solicita informações sobre } \\
\text { sesmarias e posses de terra }\end{array}$ & $18 / 09 / 1863$ & $\begin{array}{l}\text { Minas de metais e combustíveis } \\
\text { fósseis }\end{array}$ \\
\hline 21/07/1855 & Registro de terras & $10 / 10 / 1863$ & $\begin{array}{l}\text { Informações sobre a economia } \\
\text { local }\end{array}$ \\
\hline $31 / 08 / 1855$ & $\begin{array}{l}\text { Solicita informações sobre } \\
\text { sesmarias e posses de terra }\end{array}$ & $07 / 12 / 1864$ & Criação de ovelhas na província \\
\hline 21/09/1855 & $\begin{array}{l}\text { Registro de terras, aviso } \\
\text { ministerial }\end{array}$ & $28 / 02 / 1866$ & Assistência social e saúde pública \\
\hline 03/11/1855 & $\begin{array}{l}\text { Características da localidade e } \\
\text { dados populacionais, aviso da } \\
\text { diocese }\end{array}$ & $27 / 03 / 1866$ & $\begin{array}{l}\text { Atividades econômicas mais } \\
\text { expressivas }\end{array}$ \\
\hline $05 / 11 / 1855$ & $\begin{array}{l}\text { Dados da população livre e } \\
\text { escrava; condições sanitárias }\end{array}$ & $22 / 06 / 1866$ & $\begin{array}{l}\text { Características gerais da localidade, } \\
\text { dados populacionais, impostos, } \\
\text { causas do "atraso e progresso" e } \\
\text { sugestões para melhorias }\end{array}$ \\
\hline $10 / 11 / 1855$ & Registro de terras & $19 / 01 / 1870$ & Migração \\
\hline 06/01/1856 & $\begin{array}{l}\text { Produtividade da terra e dos } \\
\text { trabalhadores }\end{array}$ & $24 / 10 / 1870$ & $\begin{array}{l}\text { Aspectos da indústria, agricultura e } \\
\text { comércio; causas do "atraso e } \\
\text { progresso" nessas atividades }\end{array}$ \\
\hline $04 / 11 / 1856$ & $\begin{array}{l}\text { Agricultura, mineração e } \\
\text { "fábricas" }\end{array}$ & & \\
\hline
\end{tabular}




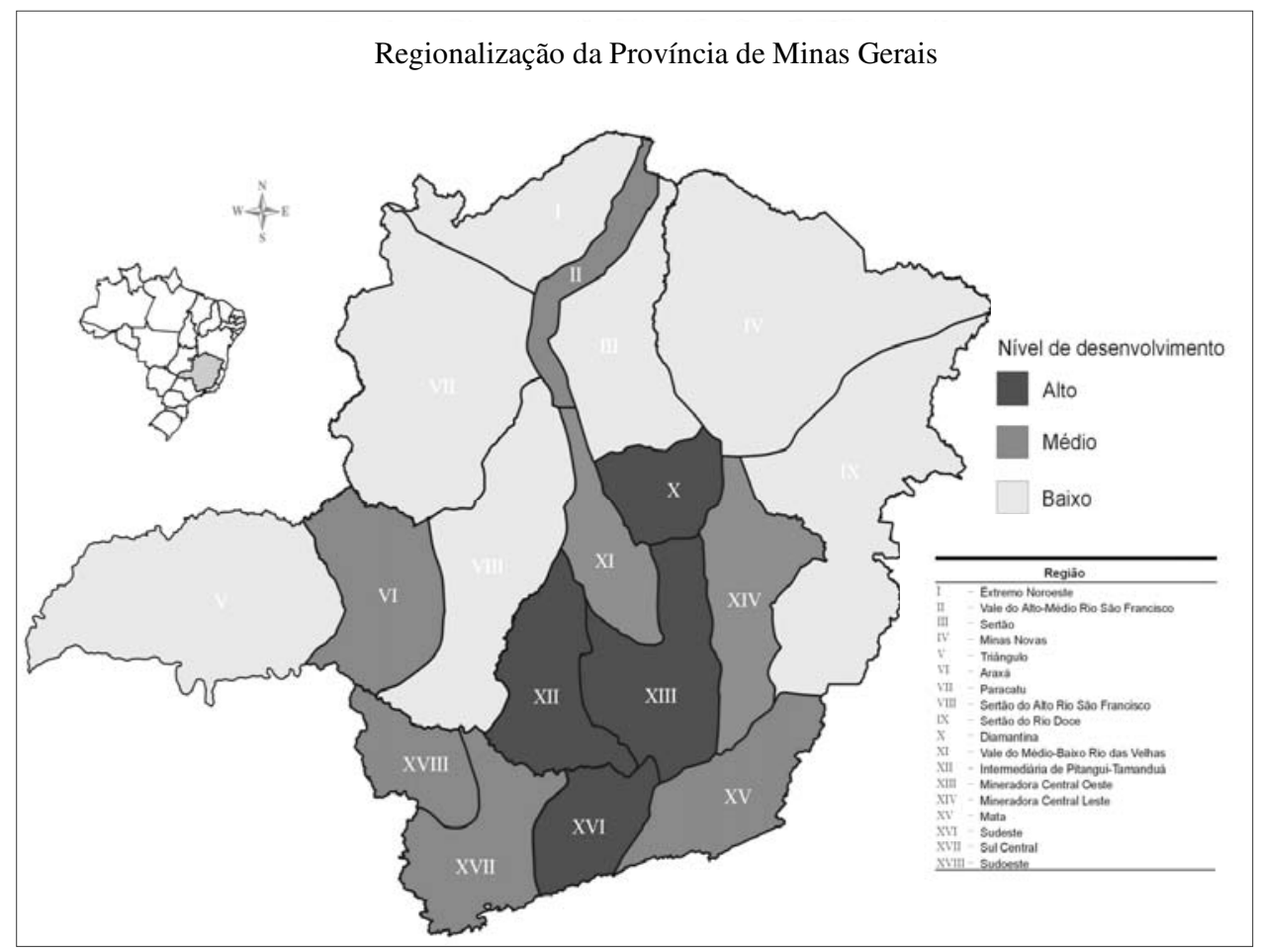

Fonte: IBGE. Malha Municipal do Brasil, 1997. Diretoria de Geociências, Departamento de Cartografia. Regionalização: Godoy (1996).

Cartografia: Ivan Sergei Matos B. Santos; Bernardo Palhares Campolina Diniz

Desenho gráfico: Alisson Luiz Prata Amorim.

\section{Planos de viação provinciais}

Dentre os temas recorrentes nos relatórios de presidentes de província, figuram as estradas de rodagem, a navegação fluvial e, a partir da década de 1860, as ferrovias. Durante todo o período imperial, os governos da província e também os deputados da Assembléia Legislativa Provincial consideraram essencial o problema dos transportes, entenderam-no como chave para o desenvolvimento econômico (Iglésias, 1958, p. 154).

A mobilização de recursos de planejamento para a intervenção do Estado no setor de transportes consubstanciou-se em três planos de viação, para os anos de 1835, 1864 e 1871. Essas programadas intervenções modernizantes não encontraram a projetada tradução prática, embora muito se realizasse no campo das obras de infra-estrutura pública viária, sobretudo na manutenção de extensa e capilarizada malha de estradas e caminhos. A distância entre os ambiciosos objetivos dos planos e as efetivas medidas implementadas se explica, principalmente, pela estreiteza dos recursos provinciais e pela eleição de outras prioridades de investimento (Iglésias, 1958: 176 e 206). Instruída por estudo de 
Demerval José Pimenta, Caminhos de Minas Gerais (1971), na sequiência apresenta-se síntese dos planos de viação da província e são avançadas algumas considerações sobre os objetivos dessas propostas de modernização dos transportes de Minas.

Ainda na primeira legislatura e orientada por advertência do presidente da província, a Assembléia Legislativa Provincial discutiu e aprovou projeto da autoria de Bernardo Pereira de Vasconcelos, que no mesmo ano foi transformado em dispositivo legal, a Lei n. 18, de 1835. Assim, o primeiro plano rodoviário de Minas Gerais objetivava a reversão do entendido como precário quadro dos transportes e comunicações herdado do período colonial (Pimenta, 1971, p. 35$40)$.

O desenho do plano revela a ambiciosa intenção de superar o isolamento geográfico de Minas Gerais. A integração da província seria alcançada através de estradas carroçáveis, que interligariam os espaços regionais internos e aperfeiçoariam a comunicação com a capital do Império. Seriam construídas quatro estradas que, procedentes de Ouro Preto, "passando pelas Cidades, e Vilas intermédias, se dirigirão as mais remotas, que ficam, para as partes do Norte, Sul, Leste, e Oeste". O projeto de desdobrar as vias de transporte, de encetar verdadeira capilarização das estradas, consubstanciava o objetivo de integração. Assim, o plano previa que, das linhas principais, deveriam partir acessos secundários "entre duas Vilas, à Vila que estiver ao lado desta, e em distancia tal, que se por ela passasse a principal, daria uma volta de mais da sexta parte". Depreende-se que das linhas-tronco ramificariam linhas laterais, através das quais várias localidades também se comunicariam com a capital da província. Quanto à ligação com a Corte, estava prevista a construção de quatro estradas, que partiriam do sul da capital da província e alcançariam a cidade do Rio de Janeiro. Além de planejar a construção desse sistema interligado, composto de vias primárias e secundárias, $o$ plano de 1835 previa a normatização das técnicas construtivas de estradas, definia minuciosos preceitos para a utilização dessas vias públicas e estipulava regulamento para a cobrança de tributos dos usuários (Livro da Lei Mineira, 1835, Tomo $1^{\circ}$, Parte $1^{\mathrm{a}}$, Folha n. 8: Lei n. $18,1 / 4 / 1835$, Artigos $2^{\circ}$ e $\left.3^{\circ}\right)^{7}$

(7) Para dar início à execução do plano, o presidente de província Antônio Paulino Limpo de Abreu, em abril de 1835 , autorizou a contratação de companhias para a construção de uma estrada, que, partindo da ponte do Rio Paraibuna - divisa de Minas com o Rio de Janeiro - seguiria para Queluz, Ouro Preto, Mariana, Itabira, Vila do Príncipe e Diamantina. Essa seria a estrada norte-sul do plano. Desta, ramificariam vias laterais para São João del-Rei e Sabará. Essa via, inicialmente chamada Estrada do Paraibuna, a partir de 1856 passou a denominar-se Estrada da Corte. Estava em processo de construção a Estrada do Paraibuna, quando Mariano Procópio Ferreira Lage, empresário mineiro, obteve privilégio exclusivo, por prazo de cinqüenta anos, para organizar uma companhia com o objetivo de construir, melhorar e conservar duas linhas de estradas. Elas deveriam começar em locais apropriados nas margens do Rio Paraíba, desde a vila do mesmo nome até o Porto Novo do Cunha, e seguiriam uma até a barra do Rio das Velhas, passando por Barbacena, com um ramal para a cidade de São João del-Rei e, a outra, por Mar de Espanha até Ouro Preto. Ambos os projetos foram alterados em seus objetivos originais, como a incorporação, em 1853, de trecho da Estrada do Paraibuna à União Indústria. Ambas sofreram forte impacto com a construção da parte mineira da estrada de ferro D. Pedro II (Pimenta, 1971, p. 41-75).

Economia e Sociedade, Campinas, v. 17, n. 2 (33), p. 159-186, ago. 2008. 
Em 1864, com o objetivo de acelerar a implantação de sistema de transportes, foi decidida a elaboração do que corresponderia ao segundo plano viário da província. Coordenado pelo engenheiro Henrique Gerber, o plano de 1864 preservou o essencial da concepção e do padrão de integração definido pelo plano de 1835. Segundo o planejamento delineado por Gerber, a articulação da Estrada de Ferro D. Pedro II com parte da União e Indústria e com alguns rios navegáveis da província constituiria a base do plano. Dessa forma, seguindo a orientação do engenheiro, o plano combinaria modalidades distintas de transportes - rodoviário, ferroviário e fluvial - e teria por eixo a Estrada de Ferro D. Pedro II. Da ferrovia ramificariam três grandes grupos de estradas-tronco: o de Sapucaí; o do Rio Grande, com o ramal do Pará; o tronco da União Indústria, com os ramais do Paraopeba, Rio das Velhas, Diamantina e Rio Doce, além de ramais menores para Mar de Espanha e Leopoldina. ${ }^{8}$ A partir de cada uma dessas linhas de transporte ramificaria uma miríade de estradas secundárias e terciárias (Pimenta, 1971, p. 77-83).

Em 1871, transcorridos sete anos, o projeto de Gerber ainda não era realidade e entendia-se necessária a imediata efetivação de medidas que permitissem o desenvolvimento dos transportes, condição então considerada indispensável para o desenvolvimento provincial. Nesse quadro, o que seria o terceiro plano viário elaborado para a província de Minas Gerais foi aprovado pela Assembléia Legislativa e sancionado através da Lei n. 1.762, de 4 de abril (Pimenta, 1971, p. 83-85).

O novo projeto previa a construção e integração de estradas de rodagem, a concessão de privilégios para a construção de vias férreas e a promoção da navegação. O plano viário de 1871 era mais simples e menos ambicioso que os anteriores, conquanto mantivesse o objetivo geral de promoção de integração nas

(8) "Cada uma destas árvores se compõe das seguintes ramificações: I - O tronco do Sapucaí (unido à estrada de ferro na Barra do Piraí). Consiste na navegação do Paraíba desde a Barra do Piraí até o Campo Belo, estrada deste último ponto ao Capivari, e navegação dos Rios Verde e Sapucaí desde o Arraial do Capivari até a Cachoeira do Salto. II - O tronco do Rio Grande consiste em uma estrada desde a Barra do Piraí até a Barra do Rio Vermelho perto de Lavras, passando perto do Bom Jardim e da Piedade, depois navegação do Rio Grande desde a Barra do Rio Vermelho até a Cachoeira da Bocaina, e uma estrada desde a Cachoeira da Bocaina até Bagagem, passando no Pium-í, Desemboque e Araxá. III - O tronco da União Indústria consiste em uma estrada desde a estação de Entre Rios (na futura estrada de ferro) até o ponto navegável do Rio das Velhas em Traíras". Desses troncos principais ramificariam, respectivamente, nove, sete e seis ramais de estradas de rodagem com os seus traçados definidos; e dessas 22 estradas secundárias partiriam outras vicinais, que não tiveram seus percursos explicitados. Por fim, foi relacionada, em separado, a navegação do "Rio São Francisco e seus tributários, que por sua parte se liga aos galhos daqueles troncos", bem como sete "vias de comunicação, que aspiram outros portos de mar do que o Rio de Janeiro: $1^{\text {a }}$. Estrada da Campanha a Jundiaí, para ligar-se à estrada de ferro de São Paulo passando em Pouso Alegre e Jaguari, com um ramal a Caldas; 2a . Estrada de São Paulo do Muriaé a S. Fidelis, com ramais a Leopoldina e Ubá; $3^{\mathrm{a}}$. Estrada de Mariana a Ponte Nova e Tombos de Carangola, para comunicar-se com o Porto da Limeira ao Itabapoana; $4^{a}$. Estrada do Porto do Guanhães até o Porto da Figueira do Rio Doce; $5^{\text {a }}$. Estrada de Minas Novas a Filadélfia e Santa Clara do Mucuri; 6a . Navegação do Jequitinhonha; $7^{\text {a }}$. Navegação do Rio Pardo" (Pimenta, 1971, p. 80-83). 
esferas intra-regional, inter-regional e interprovincial. Estava prevista a construção de 11 estradas, que interligariam localidades de diversas regiões da província, embora privilegiadas aquelas situadas nos espaços meridionais de Minas Gerais.' O plano de 1871 contemplou artigo inovador ao estabelecer divisão de responsabilidade entre Minas Gerais, São Paulo e Rio de Janeiro no concernente às comunicações interprovinciais. Entretanto, a inovação mais importante em relação aos planos anteriores é a preocupação com o desenvolvimento ferroviário. $\mathrm{O}$ instituto da garantia de juros figura como estímulo central na implantação ou expansão de linhas férreas (Saes, 1986: 30). Sem as mesmas prerrogativas e em referência imprecisa, a navegação fluvial também foi mencionada no plano, em especial nos rios Grande, Sapucaí, Baependi, Verde, Paracatu e Pardo (Pimenta, 1971, p. 85-87).

Apreciados conjuntamente, os planos de viação da província de Minas Gerais parecem informados por duas ordens de preocupações. Se as determinações da hegemonia de modelo econômico primário-exportador são discerníveis na então considerada imperativa necessidade de articular a província ao exterior, mormente à cidade do Rio de Janeiro, também é constante a influência das determinações próprias à evolução histórica da economia de Minas Gerais. Os desenhos dos planos, os sentidos das articulações progressiva e reiteradamente definidas para o sistema de transportes em construção, sugerem conflito entre a força de padrão de inserção periférica do Brasil no sistema capitalista mundial (ou os imperativos do desenvolvimento de atividades produtivas primárias orientadas para mercados externos) e as exigências de desenvolvimento econômico convergente para a "independência" (ou os imperativos de economia essencialmente não exportadora ${ }^{10}$ ).

(9) "Ficou o governo autorizado a construir as seguintes estradas: 1- De Chiador à cidade de Mar de Espanha; 2- De Rio Novo a Ubá, com ramais para o Pomba, São João Nepomuceno e Ponte Nova; 3- De Picu a Pouso Alto, Três Pontas e Alfenas, com ramais para Cristina, Baependi e Aiuruoca; 4- Da freguesia de Itajubá, atual Delfim Moreira, para a cidade de Itajubá, Pouso Alegre e Caldas, com ramal para Jaguari; 5- De São João del-Rei a Lavras e Dores da Boa Esperança; 6- De São João del-Rei para Oliveira, Formiga e Pium-í; 7. De Porto Novo do Cunha ao arraial de Meia Pataca, atual cidade de Cataguases, com um ramal para Muriaé; 8- Da cidade de Pomba para Piranga, Ouro Preto, Mariana, Santa Bárbara, Itabira, Conceição, Serro e Diamantina; 9- De Diamantina a Barra do Paraúna e a Minas Novas; 10- De Montes Claros a Extrema, atual Ibiaí, passando por Coração de Jesus; 11- De São Gonçalo da Ponte, atual Belo Vale, a Bonfim, Pará, Pitangui e Dores do Indaiá" (Pimenta, 1971, p. 85-86).

(10) O debate sobre a natureza da economia de Minas Gerais no século XIX encontra no exame dos planos de viação da província expressão clara da complexidade de estrutura econômica não redutível a padrão único de organização interna, bem como de relacionamento com o exterior. Considerado em outros termos, os planos de viação evidenciam a necessidade de conciliar os modelos interpretativos aparentemente antagônicos de Roberto Martins (1982) e Robert Slenes (1985) e reforçam a validade do modelo proposto por Clotilde Paiva (1996). Os planos de viação não apenas são incompatíveis com o padrão de desenvolvimento dos transportes observado em províncias exportadoras, portanto afirmam o caráter essencialmente não exportador de Minas Gerais, mas também salientam a existência da intenção de superação da condição de isolamento da província e de maior integração com o exterior, evidência da presença de setor exportador com elevado potencial de crescimento e que encontra nos transportes tradicionais problema fundamental. 
Nas décadas seguintes, a resolução desse conflito se baseou no gradual arrefecimento das exigências históricas direcionadas para "economia independente" e na proeminência crescente dos imperativos de integração da província, depois estado, à ordem econômica que pressupunha e estabelecia a "dependência". A modernização assente precipuamente em modelo ferroviário mostrou-se indissociável da vitória de padrão de desenvolvimento econômico que pavimentou inserção subordinada de Minas Gerais no mercado interno nacional e cingiu o Estado a décadas de estagnação relativa combinada com hesitação quanto à forma de superação do quadro de perda de importância regional e atraso relativo em relação a São Paulo. ${ }^{11}$

A terceira quadra do século XIX é ponto final de evolução histórica que remonta a meados do Setecentos e que esteve marcada pela transição da "economia do ouro" para "economia escravista de subsistência mercantil". O isolamento geográfico e os elevados custos dos transportes, principalmente quando a produção mineral declinou irreversivelmente, determinaram e sustentaram longo processo de substituição de importações e de progressiva redução da dependência externa. Minas Gerais, ainda no século XVIII, adquire auto-suficiência no abastecimento de seu mercado interno e passa a depender substancialmente apenas da importação de escravos, sal e manufaturas européias de consumo conspícuo. Verificou-se forte expansão da agricultura, pecuária, agroindústria e importante crescimento industrial. O desenvolvimento de "economia independente", entre 1750 e 1880, propiciou a emergência de elementos de uma divisão regional do trabalho e do desenvolvimento de mercado interno relativamente integrado. $\mathrm{Na}$ vigência dessas transformações, Minas Gerais apresentou elevado crescimento demográfico relativo para a população livre e foi o principal destino das importações de população cativa na primeira metade do século XIX, período que correspondeu às mais significativas entradas de escravos africanos da história do Brasil. $^{12}$

(11) Otávio Soares Dulci estudou os vários projetos de desenvolvimento regional elaborados para Minas Gerais, do início do século XX à década de 1950, que objetivaram superar o referido quadro de perda de importância regional do Estado (1999, p. 37-59).

(12) A caracterização da transição da "economia do ouro" para economia escravista de subsistência mercantil em Minas Gerais se constitui em tema recorrentemente abordado pela historiografia econômica brasileira, conquanto apenas a partir do início da década de 1980 assumiu a orientação interpretativa hoje predominante. Os trabalhos de Roberto Martins (1982) constituíram ponto de inflexão a determinar a superação das interpretações então prevalecentes, e que hoje se apresentam insustentáveis tendo em vista os substantivos avanços da produção historiográfica. Nas duas últimas décadas do século passado, muito se discutiu sobre o caráter da economia de Minas no Oitocentos, com destaque para dois modelos alternativos, propostos por Slenes (1985) e Paiva (1996), que assumiram parte da interpretação de Martins (1982), mas se fundamentaram em outros pressupostos da estrutura e dinâmica da economia provincial. A discussão da transição aqui sintetizada se baseou, para além desses autores fundamentais, em algumas referências da produção historiográfica para a segunda metade do século XVIII e primeiras décadas da centúria seguinte, como: Carrara (1997), Chaves (1999) e Almeida (1995). 
Até por volta de 1880, quando ainda não estava claramente decidido que impulsos modernizantes prevaleceriam em Minas Gerais, os transportes eram percebidos pelos governos provinciais, assim como pelos representantes no Legislativo mineiro, como passíveis de modernização com base em modelo rodoviário ou a combinação de múltiplas modalidades debaixo da hegemonia das estradas de rodagem.

\section{Transportes em Minas Gerais no final do século XIX}

Transcorridas quase quatro décadas desde a elaboração do plano viário de 1871, o sistema de transportes em gestação em Minas Gerais no final do primeiro decênio do século XX parecia claramente inclinado para modelo ferroviário, embora as estradas de rodagem e a navegação fluvial guardassem importância que era expressão de evolução histórica que remontava ao século XVIII. Essas ilações resultam do exame dos transportes representados no Mappa do Estado de Minas Geraes, carta número 21 do Atlas do Brazil, de autoria do Barão Homem de Mello e Francisco Homem de Mello, publicado em 1909. ${ }^{13}$ A escolha desse mapa justifica-se pela qualidade da representação cartográfica, pela riqueza de dados geográficos e econômicos espacializados e pela confiabilidade das fontes consultadas pelos autores.

Transpostas para base cartográfica atual e segmentadas na coleção de mapas em anexo, as informações recolhidas no Atlas do Brazil documentam o período de formação de sistema de transportes integrados em Minas Gerais. Conquanto verifiquem-se assimetrias regionais, são discerníveis múltiplas articulações entre três modalidades de transportes: estradas de rodagem, ferrovias e navegação fluvial. No processo de modernização em curso, percebe-se a decrescente importância de modelo rodoviário, que nos planos viários do século XIX parecia hegemônico, e a ascensão acelerada de modelo ferroviário. ${ }^{14}$

(13) Além do mapa de Minas Gerais, foram consultadas as informações sobre navegação fluvial constantes no capítulo V - O systema hydrographico do Brazil (Homem de Mello e Homem de Mello, 1909, p. 36-52).

(14) Dentre as informações apostas junto às cartas dos estados, a enumeração das estradas de ferro e a quilometragem respectiva são indicadores do lugar de destaque dessa modalidade no quadro dos transportes estaduais. São índices de modernidade. Em Minas Gerais eram 4.048 quilômetros de estradas de ferro em tráfego. A extensão da malha ferroviária mineira era praticamente igual à de São Paulo (4.269 quilômetros) e muito superior à dos demais estados brasileiros (Homem de Mello e Homem de Mello, 1909). Considerada a distância já bastante acentuada entre o dinamismo da economia paulista em relação a qualquer outro estado e a estreita, conquanto não exclusiva, associação entre crescimento ferroviário e produção agrícola para exportação, não resta dúvida de que o caso mineiro apresentava-se como excepcional e fundamentado em determinação não econômica. Já se manifestavam claramente os resultados da mobilização de mecanismos políticos para orientar recursos públicos para Minas, no caso através de concessões ferroviárias fortemente subsidiadas pelo governo federal (Wirth, 1982, p. 102-108). 
O Congresso Agrícola, Industrial e Comercial, realizado em Belo Horizonte, em maio de 1903, representou não apenas a tomada de consciência do atraso relativo de Minas Gerais em relação a São Paulo, mas também o fortalecimento da convicção de que a superação da estagnação econômica somente se realizaria na vigência de desenvolvimento politicamente orientado (Dulci, 1999, p. 38). A situação dos transportes de Minas Gerais no início do século XX parecia não combinar com o quadro geral da economia do Estado que os resultados das comissões do Congresso de 1903 apresentaram. O descompasso entre a aparente vitória de modelo ferroviário, bem como do ritmo de modernização do setor, que se assemelhava ao de São Paulo, em relação ao diagnóstico e proposições de intervenção na economia mineira, talvez se explique pelo artificialismo e ausência de sentido econômico da expansão ferroviária de Minas. Em outros termos, sugere-se que, no transcurso da última quadra do século XIX, a resolução daquele conflito entre duas alternativas de modernização dos transportes em Minas Gerais baseou-se em interesses não orientados pelo sentido econômico da implantação de ferrovias, ou, ao menos, desconsiderou a natureza e necessidades específicas da economia mineira (Wirth, 1982, p. 102-108).

Os atrativos de expansão ferroviária subsidiada pelo Estado e cujos principais beneficiários eram fração da elite econômica nacional e, principalmente, interesses do capital comercial e financeiro internacional, provavelmente levaram ao direcionamento de recursos públicos antes alocados em infra-estrutura de transportes rodoviários para a "febre" ferroviária da última quadra do século XIX e primeira da centúria seguinte (Saes, 1986, p. 29-79). Se o ferroviarismo paulista foi fator imprescindível ao desenvolvimento econômico com base na expansão cafeeira (Silva, 1976, p. 56), no caso mineiro talvez tenha produzido resultados mais nefastos do que virtuosos (Wirth, 1982, p. 102-108). A relativamente acelerada expansão ferroviária de Minas Gerais no último quartel do Oitocentos pode ter representado elemento essencial na perda de oportunidade histórica de desenvolvimento econômico assente em modelo alternativo. As ferrovias rompem com o isolamento geográfico de Minas antes que política de fortalecimento do mercado interno, sobretudo através de expedientes protecionistas, pudesse impulsionar a mudança de economia de base agrária, mas com importante setor de transformação, em economia industrial.

Diversas transformações são concomitantes à quebra do isolamento geográfico de Minas e à redução dos custos dos transportes interprovinciais, depois interestaduais. Assim, nas décadas finais do século XIX, observa-se: estagnação da agropecuária acompanhada de progressiva incapacidade de atendimento das necessidades do mercado interno mineiro; crescimento das importações e ampliação da dependência externa (Iglésias, 1982, p. 123); desestruturação das atividades artesanais e manufatureiras tradicionais (Libby, 
1988); industrialização relativamente lenta e descontinuada (Giroletti, 1988, p. 116-131); desaceleração do crescimento populacional e início de movimento emigratório que atingiu grandes proporções no transcurso do século XX (Wirth, 1982, p. 50; Dulci, 1999, p. 44); dentre outras transformações que configuraram o quadro de crise que mobilizou a convocação do Congresso Agrícola, Industrial e Comercial de 1903. A elite política e econômica reunida no Congresso propôs a recuperação de vocação histórica como medida para a superação da crise da cafeicultura, a diversificação econômica se apresentou como caminho para repor Minas em posição proeminente perdida (Iglésias, 1982, p. 119-120; Dulci, 1999, p. 43-53). No entanto, a partir da década de 1880, apresentavam-se cada vez mais fortes as evidências de que a província, depois estado, rumava para inserção periférica no processo de integração do mercado nacional. A economia mineira entrou em longo período de estagnação, indefinição e crescente dependência. Somente na década de 1940, começou a despontar orientação econômica que preconizava a especialização industrial com base na intervenção estatal e capital estrangeiro, em quadro de integração à divisão regional do trabalho hegemonizada por São Paulo (Diniz, 1981; Dulci, 1999, p. 93-124).

\section{O problema dos transportes nas dimensões local e regional}

A documentação recolhida sobre o tema dos transportes, nos inquéritos provinciais, é rica em evidências, sobretudo de natureza mercantil, da complexidade das articulações intra-regionais, inter-regionais e interprovinciais de Minas Gerais na terceira quadra do século XIX. Visão de conjunto sugere que o problema dos transportes decompunha-se em interesses variados, portanto irredutíveis a sentido único. A acentuada capilaridade das estradas, caminhos e linhas de navegação fluvial refletia a associação de necessidades internas com externas. Múltiplas determinações informavam o posicionamento das autoridades municipais no diagnóstico e proposição de intervenção nos transportes locais e regionais. Estavam debaixo dos imperativos incontornáveis da realidade do comércio, abastecimento, acesso a serviços públicos, circulação de informações e comunicação social das circunscrições administrativas pelas quais respondiam.

Na seqüência, examina-se conjunto de excertos que demonstra a vigência das mencionadas determinações e imperativos que presidiam a percepção, enquadramento e proposição de intervenção na infra-estrutura de transportes de municípios e freguesias. Foram selecionados extratos de respostas a solicitações do governo provincial referentes a várias unidades administrativas, distribuídas por diversas regiões de Minas. As unidades regionais que regularmente são referidas no transcurso da análise podem ser visualizadas na representação cartográfica constante na primeira parte do texto. 
O problema do abastecimento, principalmente da extensa rede urbana da província, ensejava a permanente preocupação com a transitabilidade das estradas e talvez se constituísse na mais importante razão para a solicitação local de manutenção ou ampliação da infra-estrutura de transportes. Os dois documentos reproduzidos abaixo refletem a relação direta entre o estado das estradas e o regular abastecimento dos centros urbanos. Sugerem também que as crises de abastecimento poderiam resultar mais das dificuldades ou impossibilidade de circulação de mercadorias do que da ausência ou insuficiência de excedentes da agropecuária. Em atendimento a solicitação da Presidência da Província, de 16 de março de 1859, dois fazendeiros, da região Mineradora Central Oeste, respondem sobre as razões da interrupção do fluxo de alimentos para Ouro Preto.

Tive entre mãos honrosa carta de V. Ex.a com o fexo de 16 do corrente e passando a responder o contexto da mesma sou a dizer a V. Ex.a que havendo geralmente a falta de viveres, nem só aqui como noutros lugares como me consta, e mesmo Fazendeiros que nunca soffrerão, assim como eu que nunca me vi nas circunstancias de recorrer a outros e agora me acho nessa prosicao, esse o grande motivo por que os tropeiros não acham para conduzir pra essa, e não duvido que no centro dos matos haja algum mantimento; porem a estação chuvosa pós as estradas de tal maneira que prohibio o tranzito. Hé o quanto tenho de levar ao conhecimento de V. Ex.a a quem Deus Guarde muitos anos. (Fazenda da Água Fria, 27 mar. 1859 - Arquivo Público Mineiro, Seção Provincial, códice SP 767).

Tive a honra de receber a Circular de V. Ex.a de 16 do corrente na qual me convida para mandar minha tropa a essa Cidade, declarando ser falso o boato de epidemia de bexigas, e atribuindo a esse falso boato a falta de concorrencia de tropas carregadas de generos allimentícios: tenho a honra de responder a V. Ex.a que, não he o boato de epidemia que veda o ingresso das tropas nessa cidade, e sim a falta de absoluta de estradas nas estações chuvozas como acontece presentemente, pois que das deste Arraial the perto da cidade de Mariana só passão as tropas com grande trabalhos e graves prejuízos, ora, não havendo abundancia de generos, e antes havendo falta delles por aqui, não nos convem aventurar as tropas em huma estrada em que cabe perfeitamente o nome de abismo; considerando porem a falta que sofre a classe menos abastada d'essa cidade, vou envidar meus esforços a fim de chegar ahi minha tropa com algum carregamento. (Fazenda do Café da Barra do Bacalhau, 29 mar. 1859 - Arquivo Público Mineiro, Seção Provincial, códice SP 767).

O comércio interno e externo de Minas Gerais, província interior, dependia estruturalmente da qualidade das vias de transporte. Os elevados custos dos transportes representavam pesado ônus para a produção de subsistência mercantil e configurava-se na principal variável para produtores que orientavam regularmente seus excedentes para mercados de média e longa distância. O dinamismo do comércio inter-regional e interprovincial estava condicionado pela qualidade da infra-estrutura de transportes. Os excertos a seguir demonstram a elevada importância do nível de desenvolvimento dos transportes para o crescimento da circulação de mercadorias nas décadas de 1850 e 1860 . São 
respostas de diversas câmaras municipais a solicitações da Presidência da Província sobre temas econômicos.

A segunda pergunta, respondo, que os fazendeiros, criadores do Sertão, não remettem hoje gados para a Corte, mas sim esperão o comprador no mercado d' Uberaba, porque, existindo o monopólio das companhias ou sociedades marchantes da Corte, tem acontecido, que o negociante Mineiro, chegando á Corte com marchas pereciveis, e immensas despezas, vio-se por muitas vêses obrigado a vender os seus gados por prêços módicos, inferiores ao custo e valor do gado, soffrendo assim grandes prejuizos, pois que as comapanhias, sendo as unicas compradôras, e não podendo os negociantes voltar para Minas, com os seos gados, não tinhão outro remedio sinão sugeitar-se ao prêço dos marchantes, e deste modo é que se-affugentou do mercado a maior parte dos negociantes de Minas; fazendo com que o marcante, vendendo o gado por preço vantajoso e à varêjo, realizasse grandes lucros, e o Mineiro immensos prejuízos. (Câmara Municipal de Uberaba, região do Triângulo, 8 jan. 1858 - Arquivo Público Mineiro, Seção Provincial, códice SP 715).

(...) a exportação para o Rio de Janeiro, Cidades Diamantina e do Sabará é feita com extremo sacrifício até o presente por falta de estradas que dêem transito livre e sem algum perigo (...) (Câmara Municipal de Tamanduá, região Intermediária de Pitangui e Tamanduá, 12 jan. 1858 - Arquivo Público Mineiro, Seção Provincial, códice SP 655).

Em tempos de abundancia muitas vezes vê o Agricultor seus cereaes apodrecerem em seus paioes, sem que os exportem, por que os mais das vezes o preço por que são vendidos, não cobrem as grandes despezas para os levar ao mercado. A falta absoluta de estradas muito concorre para que a lavoura n'este Município não esteja ainda em hû estado de florescência, que poderia estar. As estradas que prezentemente temos são trilhos, em grande parte verdadeiros tremendois, onde ordinariamente os tropeiros vêem desfalcar sua tropa; d'ahi rezulta os altos preços, que pagão os lavradores com o transporte de seus generos ate aos mercador de S. Fidelis, Ponto do Cardoso, Juiz de Fora e outros.(...) Esta câmara esta plenamente convicta que as maiores necessidades do seo município, são ouro, ouro e mais ouro; com esse precioso meio se farão vias de fácil communicação para a exportação do caffé e mais generos; com esse motor do mundo se farão pontes em Rios, e volumozos Ribeirões, que em tempos pluviosos inibem a passagem as tropas, e viajares, feito o que removidas estarão suas maiores necessidades, e aumentados os seos recursos. (Câmara Municipal de Muriaé, região da Mata, 11 maio 1866 Arquivo Público Mineiro, Seção Provincial, códice SP 1157).

A producção e criação, e em geral o commercio poderião ser muito maiores do que são, se não fossem algumas causas que infelizmente os tem feito estacionar; quaes sejam, a falta de pontes e estradas que communique esta Cidade com a Côrte e com o interior, como a Câmara por veses já tem feito ver a esse Governo, faltas essas que tem levado o commercio do interior, que outrora formava nesta cidade como que um empório, a outros mercados. Este inconveniente, porem, espera esta Câmara ver desapparecer com a construção da projetada estrada que da Formiga se dirige a entroncar-se na da União e Industria, passando pela Oliveira, esta cidade São José e 
Barbacena notada ultimamente pela Assemblea Provincial e pelo melhoramento da do Bom Jardim a procurar a estrada de ferro de D. Pedro II, e finalmente com os reparos e construcções de diversas pontes, para as quaes a mesma Assemblea tem notado fundos, o que fará este Município prosperar, e por conseqüência augmentar sua industria, producção e criação. (Câmara Municipal de São João del-Rei, região Sudeste, 12 maio 1866 - Arquivo Público Mineiro, Seção Provincial, códice SP 1157).

Dois documentos, para os anos de 1855 e 1866, elaborados por autoridades da Câmara Municipal de Grão Mogol em resposta a uma solicitação da Presidência da Província, são emblemáticos da justaposição de determinações de distintas naturezas a instruir a percepção das autoridades locais quanto ao problema dos transportes. Transcorridos mais de dez anos, permaneciam inalteradas as dificuldades postas pelas condições de transitabilidade das vias de transporte do município localizado na região de Minas Novas, no norte de Minas Gerais. Abastecimento, comércio, administração pública e circulação de informações apresentavam-se seriamente prejudicadas pelo baixo desenvolvimento da infra-estrutura de transportes. As autoridades de Grão Mogol consignaram com especial dramaticidade as conseqüências da precariedade ou inexistência de pontes. Em província com relevo acidentado e capilarizada malha hidrográfica, a passagem dos cursos d'água, sobretudo nas estações de elevados índices pluviométricos, representava obstáculo quase instransponível à circulação de pessoas, mercadorias e informações. Cabe ainda destacar as impressionantes articulações da vila de Grão Mogol que, apesar de distante dos espaços regionais mais dinâmicos de Minas Gerais e das grandes dificuldades dos transportes, mantinha vinculações, sobretudo comerciais, com vários centros regionais do norte da província, com a cidade do Rio de Janeiro e com a Bahia.

(...) neste Município não existe ponte alguma, por cuja falta tanto sofrem o comercio e a Publica Administração sortindo como presentemente, que, cercada a vila de Rios e Ribeirões Caudalosos, nas grandes enchentes, ficão interceptados todas as communicações, e transportes de gêneros de consummo, sendo por isso de absoluta necessidade que, alem da ponte do Rio Itacambirussú, cuja construção foi a Arrematada, se construão mais quatro pontes sobre os Rio Vacaria, e Ventania, e Ribeirões de Santo Antonio e Estrema, que apenas são vadeáveis durante a seca, tornando-se intransitáveis em toda a estação pluviosa (...) (Câmara Municipal de Grão Mogol, 10 jan. 1855 - Arquivo Público Mineiro, Seção Provincial, códice SP 570).

O município recente-se de falta de pontes, e estradas: o cofre da Municipalidade, no concurso de particulares derão existência a duas bôas estradas, em duas boas, digo, em duas estradas pra esta Cidade. A falta de uma ponte sobre o Rio Itacambirussú, onde existe apenas ua má estiva levadiça feita pro particulares, traz, no tempo invernoso serios embaraços, e inconvenientes à esta Cidade, com escassez muito sensivel de generos alimentícios, e por conseqüência elevação delles a preços fabulosos pelos taberneiros; prejuizo na marcha do serviço publico, e do comercio 
pela impossibilidade de transito dos correios, estafetas, tropas, porque as enchentes não permittem a permanência da estiva, a qual alias em todo do tempo ameaça perigo eminentissimo. Releva consignara aqui um facto bem significativo: em o anno passado, quando por ordem do Ex.mo Governo retirava-se d'aqui com urgência um destacamento de Praças do Corpo Policial para o Matto-grosso, foi elle obrigado a deter-se para não poder transpor o Itacambirussú: só depois de longo tempo procurou-o com sacrifícios, e grande morosidade, caminhos diferentes em busca de outra passagem para poder seguir viagem, cumprir a ordem superior. $\mathrm{He}$ assim que as relações deste Município com os da Diamantina para onde convergem todas as suas transações comerciais, de Minas Novas, Serro e finalmente com toda a parte que se dirige para o Sul da Província, ate a Corte, ficam suspensas pela carência de ponte no Itacambirussú, Rio volumoso, de uma corrente imensamente forte, e rápida inacessível a Canôas, que em abril deste ano fez ainda duas vitimas o doutor em medicina Ignácio Belzer, e o relojoeiro suisso Carlos Petero, facto este que foi infelizmente reprodução de semelhantes e não poucos freqüentes. Há mais, entre outros, dous rios quase nas condições do que occupa nossa atenção - o Ventania, que liga este Município com os Arraiais de Salinas, e muito especialmente com os do Calhau, e Itinga, donde afluem para o mercado desta cidade o sal, e diferentes gêneros procedentes da Bahia, e o Vacaria - na estrada que desde a Diamantina, e deste Município, e cidade, segue para a Villa do Rio Pardo, ate a Província da Bahia, Lavras do Sincorá, freqüentadas por negociantes do Grão Mogou. (Câmara Municipal de Grão Mogol, 26 jul. 1866 - Arquivo Público Mineiro, Seção Provincial, códice SP 1157).

Em resposta à circular da Presidência da Província sobre as pontes da municipalidade, a Câmara de Barbacena realça que nomeou comissão para elaborar diagnóstico do estado de conservação e trânsito dessas obras viárias. O território do município de Barbacena dividia-se entre porções das regiões Sudeste e da Mata, sendo que a sede localizava-se em ponto privilegiado para o qual convergia grande parte do comércio de importação e exportação de Minas Gerais. A descrição do estado das pontes do município e a avaliação dos recursos necessários para reparação ou reerguimento contrastam com a penúria de Grão Mogol, que aparentemente não possuía uma única obra viária dessa natureza. Essa assimetria revela desigual distribuição de recursos públicos, acentuada ainda mais pelo processo de modernização dos transportes das décadas seguintes. No relatório da comissão que examinou as pontes do município se destacam os múltiplos vínculos comerciais de Barbacena com várias regiões da província, a função de intermediação mercantil da cidade em relação a espaços regionais distantes e a provável capacidade de arregimentação de recursos públicos expressa na nada desprezível importância requerida para o reparo ou reconstrução das pontes do município.

A comissão lembra se que quando a Camara exigiu do Exmo Governo a quota de $300 \$ 000$ era então somente para um simples reparo [da ponte sobre o Rio Barroso]; hoje porem hé para fazê-la inteiramente de novo, por quanto as grandes enchentes de a pouco arrasarão-na de todo em tudo, a questão mudou pois de face. Mostra-se 
a grande importância desta Ponte por isto: ella serve de communicar esta Cidade com a de S. João de El Rey entretendo com esta duas povoações um comercio não pequeno, praticado tanto por tropas, como por carros, e alem disto he hum dos principais ramos de Linha do Paraibuna. Ponte Nova $=$ Cerca de seis meses passei por esta ponte, e notei no seu estado de ruína, que tem se augmentado grandemente. Sua importancia e necessidade he palpável; por isso que esta ponte communica esta cidade com o Rio Preto abrangendo grande numero de Fazendeiros, que a esta cidade vem fazer seus negócios. He estrada muito freqüentada, como todos nós sabemos. A comissão he de parecer que a Camara peça ao Exmo Governo a quota de 500\$000 para seu reparo. Ponte do Cosme. Communica esta cidade com o arraial de Santa Rita da Ibitipoca ate o Piçarrão, e um considerável numero de fazendeiros que tem relaçoes comerciais e forenses nesta cidade. Bem claro está a sua importância e utilidade, e por isso a Comissao é de parecer que a Camara peça ao Exmo Governo $250 \$ 000$ para seo melhoramento. Pombal = Communica esta Cidade com toda a matta que nos fica ao Nascente, donde nos vem o abastecimento de toda a espécie de viveres, e passando pela Pomba Mercês, Rio Novo, e Contagallo, vai ate Campos: da na vista sua importância, necessidade, e utilidade. A Comissão nota que esta ponte está mui arruinada, e he de parecer que para seo concerto é mister a quantia de $250 \$ 000$. Ponte do Corocotó $=$ Communica esta cidade com o Sertão do interior que nos fica ao Noroeste, donde vem considerável numero de boiadas, queijos, toucinhos, courama e solla: he evidente sua importância, e necessidade, e por isso a Comissão he de parecer que para seu reparo necessita de 150\$000. Ponte da Caveira, ou da Boa Vista. Desnecessario he falar de sua importancia, basta dizer se que he a continuação da Estrada do Paraibuna para a capital da Província: a Comissão orça em $150 \$ 000$ o seu concerto. Ponte da Joanna. Corta um bairro da povoação desta Cidade, cujos habitantes transitão por ella diariamente, e alem disto he um ramal da estrada que segue para a capital da Provincia. A Comissão orça em $150 \$ 000$ o seu reparo. Ponte da Caieira. Será construída sobre o rio Salgado, he seguimento da estrada daqui para a de São João de El Rey. Fala-se em construir, por que aqui havia foi radicalmente levada pelas enchentes de a pouco. (Câmara Municipal de Barbacena, 11 jan. 1855 - Arquivo Público Mineiro, Seção Provincial, códice SP 570).

Como nos casos de Barbacena e Grão Mogol, para muitos outros municípios é possível reconstituir a presença de vias de transporte que sustentavam a existência de fluxos comerciais internos e externos à província e que indiciavam algumas condições necessárias ao processo de integração do mercado interno de Minas Gerais. Em outros termos, são exemplos conspícuos de que uma outra modernização dos transportes era possível em província com mercado interno relativamente dinâmico. Demonstrações adicionais de múltiplas articulações intra-regionais, inter-regionais e interprovinciais são os três documentos reproduzidos a seguir. Caldas, na região Sul Central; Pomba, na região da Mata, e Serro, na região de Diamantina, são casos que reafirmam a inexistência de direção única dos transportes de Minas Gerais, ao contrário, afirmam a convivência entre vínculos com o exterior e articulações internas, mesmo quando a proximidade de importantes mercados externos poderia 
monopolizar as relações mercantis, como é o caso de Pomba, em relação ao Rio de Janeiro, e Caldas, em relação a São Paulo.

Exmo Sr. todos estes concertos e facturas de pontes em arelação mencionada são da mais palpitante necessidade, principalmente o concerto da ponte nova no Rio Pardo, no caminho que segue desta para a Freguesia de Cabo Verde e anova construcção da ponte no mesmo Rio Pardo na estrada nova que segue desta para a Freguesia do Campestre, e dali para outros lugares do município, e de onde vem o abastecimento de mantimentos para esta vila.(...) Numero das pontes no Municipio de Caldas. Existentes no Município 8 pontes asaber. Duas no Rio Pardo, sendo uma na estrada que segue desta Villa para Freguesia do Cabo Verde, Jacuhy, Passos, e centro da Província. Outra que segue igualmente desta Villa para Pouso Alegre, Campanha, Rio de Janeiro, e Capital da Província. No Rio Verde tao bem duas, uma na estrada que vai para a província de S. Paulo, por onde transita grande numero de tropas soltas, ditas carregadas, e Boiadas que seguem para o Rio. sendo outra na estrada que segue desta vila para os poços das águas calidas, e freguesia do Sapecado, e Caconde, e de serventia de um grande numero de Fazendeiros. Huma sobre o Rio Capivary, e outra no Rio Maxado, as duas na estrada aque segue desta Vila para a S. Gonçalo, Campanha, e Capital da Província. Duas mais, uma sobre o Rio Cabo Verde e outra sobre o Rio Mosambo, ambas na estrada que segue da Freguesia de Cabo Verde para a de Alfenas, e Rio de Janeiro. (Câmara Municipal de Caldas, 9 jan. 1855 - Arquivo Público Mineiro, Seção Provincial, códice SP 570).

A Câmara Municipal desta Villa de S. Manoel da Pomba, em resposta a circular de V. Exa. de 11 de novembro do anno proximo passado, tem a honra de informar a V. Exa. que a industria deste Termo, é toda agrícola, não consta haver mineração de espécie alguã, e muitos são os estabelecimentos de Engenhos onde fabricão assucar, e aguardente, e também se cultiva o caffe em não pequena escalla, sendo a exportação deste genero, e do toucinho a principal. A criação de gado, hé insignificante, pela falta de pastos nativos, e de salinas. O comercio, hé prospero, e não hé muito que a sua importação se calcule em quatro centos contos de reis e a exportação acima de oito centos conto anuaes, e as medidas mais convenientes para o progressivo augmento, seria a abertura da estrada, que da Sapucaia cortasse para esta vila, e fosse ter a Piranga, cuja picada já fora aberta a tempos a expenças da Câmara, e Povo deste Município, e também aliás vantajoso seria, que por aqui passasse um ramo da Estrada da Companhia União e Industria; com a abertura destas estradas está a Câmara convencida, que este Município, apesar de pequeno se tornaria um dos principais da Província, não só pela benignidade do seu clima, fertilidade de suas terras, como tao bem por se achar perto do mercado principal. (Câmara Municipal de Pomba, 8 jan. 1855 - Arquivo Público Mineiro, Seção Provincial, códice SP 570).

(...) Esta indústria já bastante importante he ainda susceptível de hum progresso imenço indefinido; para o que bastava empregar-se os meios seguintes: $1^{\circ}$ melhoramento da viação das freguezias do leste para esta Cidade, e desta cidade para a Diamantina; reabertura da estrada que já existio entre o Pessanha, e o Porto da Figueira nas margens do Rio Dôce, e sobre tudo a communicação que se projecta directamente entre este Município e a costa pelo vale de São Matheus; $2^{\circ}$ e concluindo isto que depende somente do Excelentíssimo Governo realizar, 
completar a obra da regeneração da agricultura (...). (Câmara Municipal do Serro, 8 jan. 1859 - Arquivo Público Mineiro, Seção Provincial, códice SP 779).

Conclui-se que os inquéritos reúnem evidências documentais das referidas determinações refletidas nos planos viários e permitem demonstrar a sobreposição das mencionadas articulações internas e externas de Minas Gerais. O exame das respostas aos inquéritos das décadas de 1850 e 1860 evidenciou alguns dos atributos da economia de Minas Gerais anteriormente discutidos, mormente as exigências próprias de orientação econômica não exportadora, portanto independente de injunções externas. A modernização dos transportes emerge como condição para o fortalecimento do mercado interno combinado com o robustecimento das relações com o exterior de Minas.

\section{Referências bibliográficas}

ALMEIDA, Carla Maria C. Minas Gerais de 1750 a 1850: bases da economia e tentativa de periodização. LPH - Revista de História, Mariana: ICHS/UFOP, n. 5, 1995.

ARQUIVO PÚBLICO MINEIRO. Seção Provincial, Documentação Encadernada. Códices 569, 570, 609, 610, 612, 654, 655, 656, 714, 715, 767, 779, 832, 834, 898, 945, 949, 955, 956, 958, 1005, 1006, 1007, 1055, 1056, 1085, 1157, 1379.

CAPELATO, Maria Helena R. (Coord.). Produção histórica no Brasil, 1985-1994: catálogo das dissertações e teses dos programas e cursos de história. São Paulo: Editora Xamã, 1995.

CARRARA, Angelo Alves. Agricultura e pecuária na capitania de Minas Gerais (16741807). Tese (Doutorado)- IFCS/UFRJ, Rio de Janeiro, 1997.

CHAVES, Cláudia Maria das Graças. Perfeitos negociantes: mercadores das minas setecentistas. São Paulo: Annablume, 1999.

DINIZ, Clélio Campolina. Estado e capital estrangeiro na industrialização mineira. Belo Horizonte: UFMG/PROED, 1981.

DULCI, Otávio Soares. Política e recuperação econômica em Minas Gerais. Belo Horizonte: Editora da UFMG, 1999.

FERREIRA, Gabriela Nunes. Centralização e descentralização no Império, o debate entre Tavares Bastos e visconde de Uruguai. São Paulo: Departamento de Ciência Política da Universidade de São Paulo, 1999.

FRAGOSO, João Luís. Economia brasileira no século XIX: mais do que uma 'plantation' escravista-exportadora. In: LINHARES, Maria Yedda (Org.). História geral do Brasil. 9. ed. Rio de Janeiro: Campus, 2000.

GIROLETTI, Domingos. A industrialização de Juiz de Fora. Juiz de Fora: EDUFJF, 1988.

GODOY, Marcelo Magalhães. Intrépidos viajantes e a construção do espaço: uma proposta de regionalização para as Minas Gerais do século XIX. Belo Horizonte: Cedeplar/UFMG, 1996. (Texto para discussão, n. 109). 
GOULART, José Alípio. Meios e instrumentos de transportes no interior do Brasil. Rio de Janeiro: MEC, Serviço de Documentação, Departamento de Imprensa Oficial, 1959.

HOMEM DE MELLO, Barão; HOMEM DE MELLO, Francisco. Atlas do Brazil. Rio de Janeiro: F. Briguiet \& Companhia, 1909.

IGLÉSIAS, Francisco. Política econômica do Estado de Minas Gerais, 1890-1930. In: SEMINÁRIO DE ESTUDOS MINEIROS, 5, Belo Horizonte, UFMG, 1982.

. Política econômica do governo provincial mineiro, 1835-1889. Rio de Janeiro: Instituto Nacional do Livro, 1958.

LAPA, José Roberto do Amaral. O interior da estrutura. In: SZMRECSÁNYI, Tamás (Org.). História econômica do período colonial. 2. ed. São Paulo: Hucitec/ABPHE/ Edusp/Imprensa Oficial, 2002. [p. 163-171].

LIBBY, Douglas Cole. Transformação e trabalho. São Paulo: Brasiliense, 1988.

LIVRO DA LEI MINEIRA, 1835, Tomo $1^{\circ}$, Parte $1^{\text {a }}$, Folha n. 8: Lei $n$. 18, 1/4/1835.

MARTINS, Roberto Borges. A economia escravista de Minas Gerais no século XIX. Belo Horizonte: Cedeplar/UFMG, 1982. (Texto para discussão, n. 10).

NATAL, Jorge Luiz Alves. Transporte, ocupação do espaço e desenvolvimento capitalista no Brasil: história e perspectivas. Campinas: Instituto de Economia da Unicamp, 1991.

PAIVA, Clotilde Andrade. População e economia nas Minas Gerais do século XIX. Tese (Doutorado)- FFLCH-USP, São Paulo, 1996.

PAULA, João Antônio. O mercado e o mercado interno no Brasil: conceito e história. História Econômica e História de Empresas, São Paulo: ABPHE, v. 5, n. 1, p. 7-39, 2002.

PIMENTA, Demerval José. Caminhos de Minas Gerais. Belo Horizonte: Imprensa Oficial, 1971.

QUEIROZ, Paulo Roberto Cimo. Transportes e comunicações no Brasil: breves considerações sobre as fontes para a sua história. América Latina en la História Econômica, n. 14, ene./dec. 2000.

RODARTE, Mario Marcos Sampaio. A pertinácia das minas que não se esgotaram. Dissertação (Mestrado)-Cedeplar/UFMG, Belo Horizonte, 1999.

SAES, Flávio A. M. de. A grande empresa de serviços públicos na economia cafeeira, 1850-1930. São Paulo: Editora Hucitec, 1986.

SILVA, Sérgio. Expansão cafeeira e origens da indústria no Brasil. São Paulo: Editora Alfa-Ômega, 1976.

SLENES, Robert W. Os múltiplos de porcos e diamantes: a economia escravista de Minas Gerais no século XIX. Cadernos IFCH, Campinas, IFCH/Unicamp, n. 17. 1985.

WIRTH, John D. O fiel da balança: Minas Gerais na federação brasileira, 1889-1930. Rio de Janeiro: Editora Paz e Terra, 1982. 
Marcelo Magalhães Godoy / Lidiany Silva Barbosa

\section{Anexo Cartográfico}

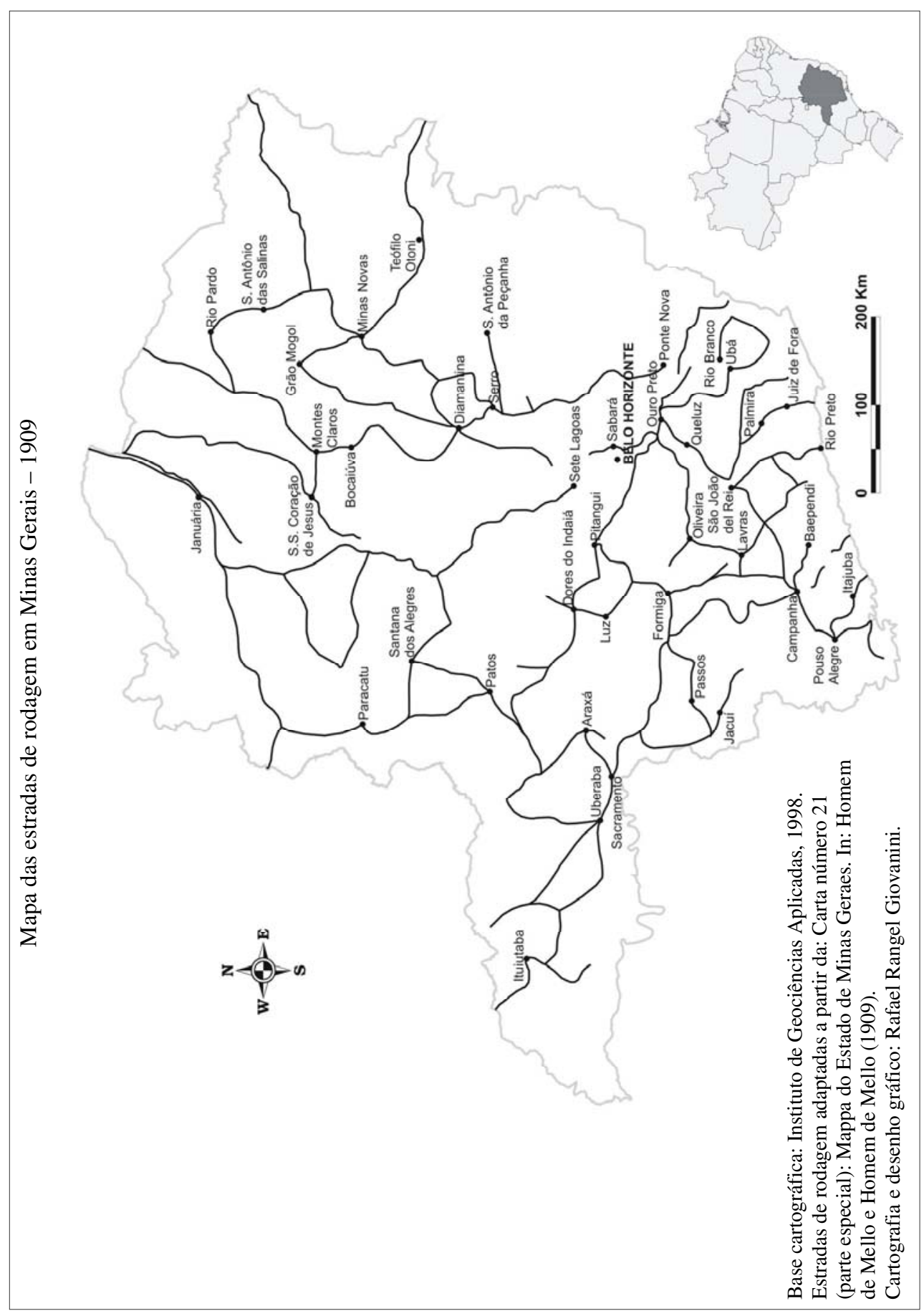




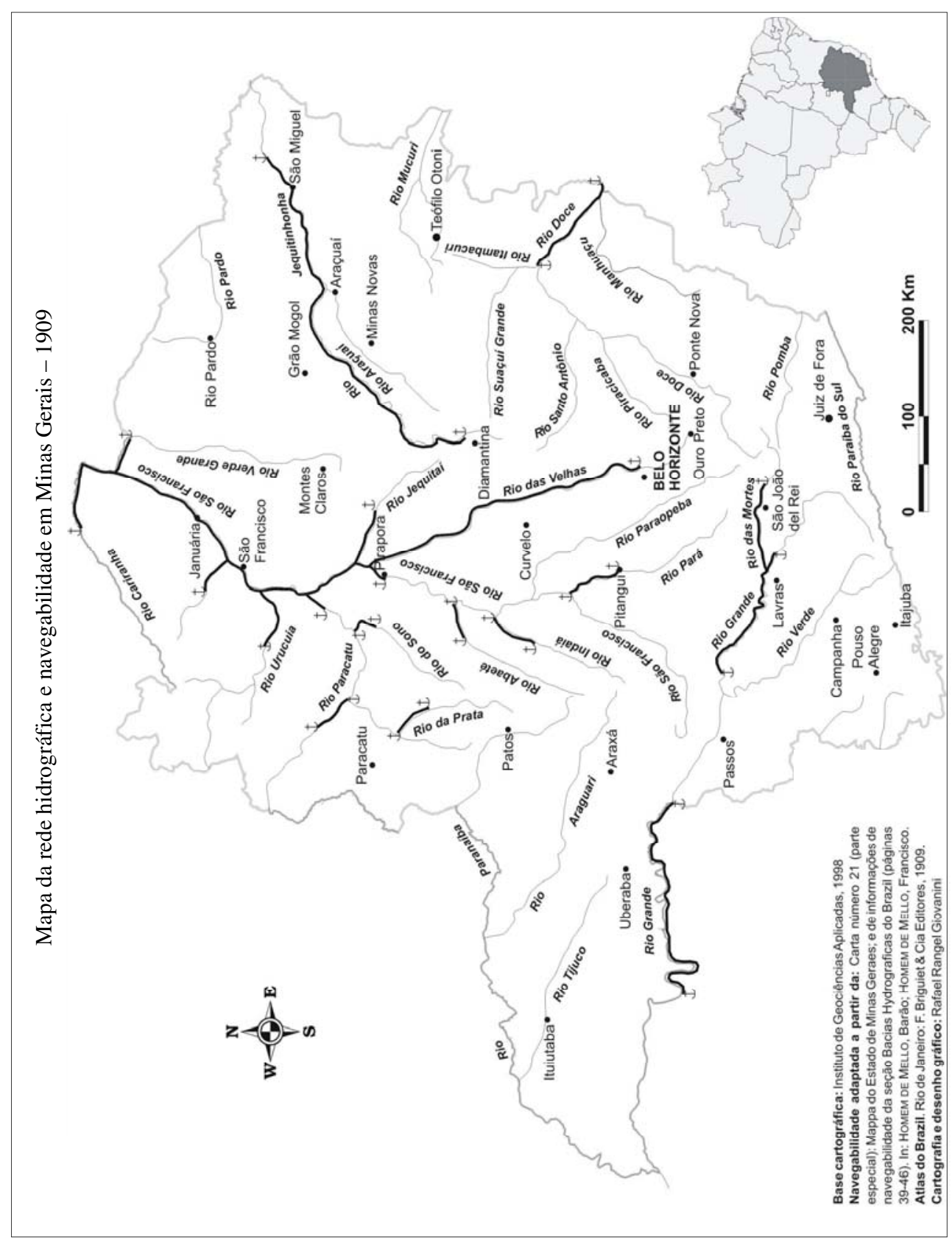




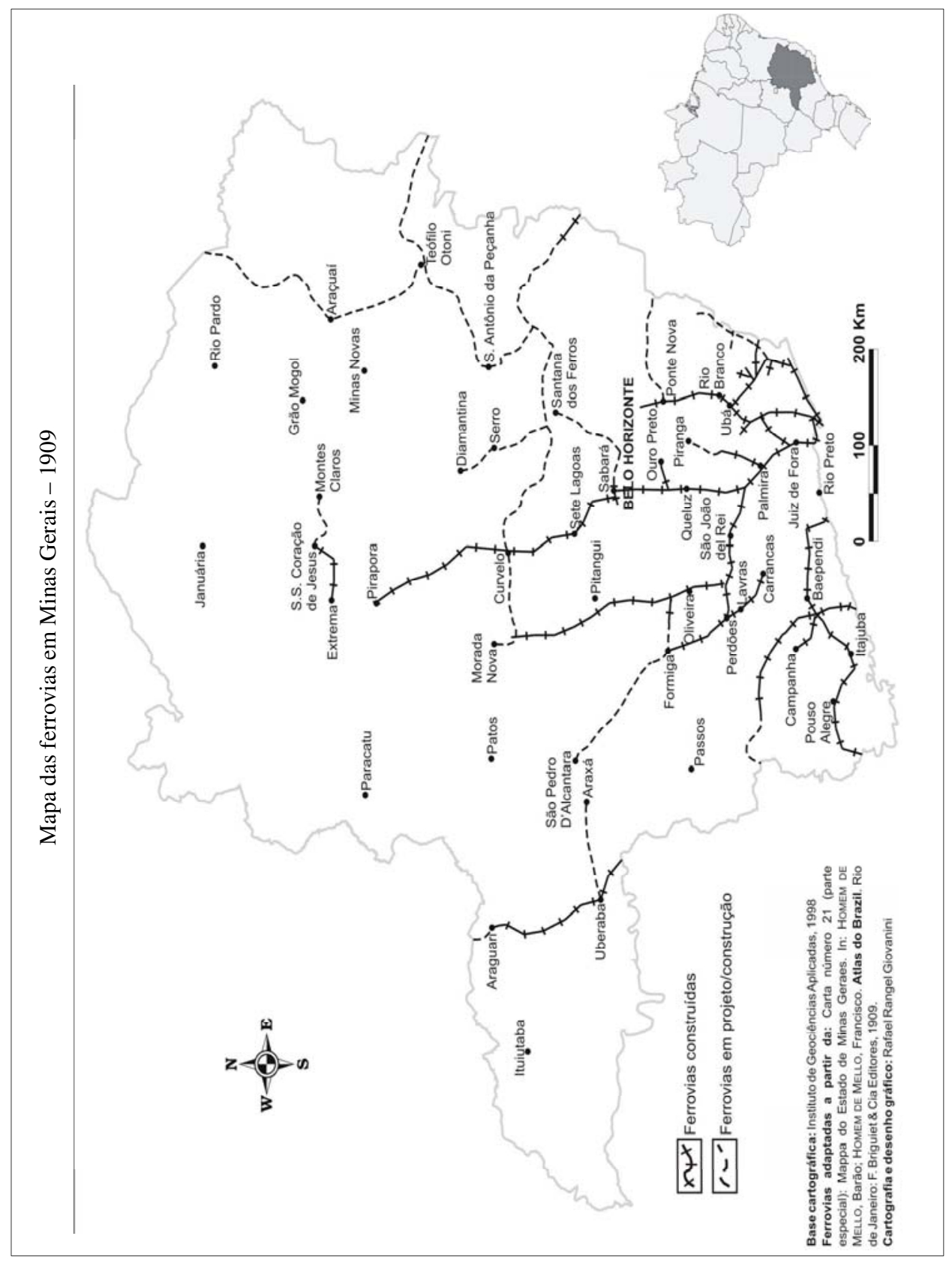

